\title{
The Anatomy of Bank Diversification
}

Ralf Elsas, Andreas Hackethal, and Markus Holzhäuser

Discussion Paper 2006 - 1

August 2006

Munich School of Management

University of Munich

Fakultät für Betriebswirtschaft

Ludwig-Maximilians-Universität München

Online at http://epub.ub.uni-muenchen.de 


\title{
The Anatomy of Bank Diversification ${ }^{1}$
}

\author{
Ralf Elsas $^{2}$, Andreas Hackethal ${ }^{3}$, Markus Holzhäuser ${ }^{4}$
}

\begin{abstract}
:
We use panel data from nine countries over the period 1996 to 2003 to test how revenue diversification in conjunction with increasing bank size affects bank value. Using a comprehensive framework for bank performance measurement, we find no evidence for a conglomerate discount, unlike studies concerned with industrial firms. Rather, revenue diversification increases bank profitability and is associated with higher market valuation. This performance effect does not depend on whether diversification was achieved through organic growth or through M\&A activity.
\end{abstract}

\footnotetext{
${ }^{1}$ We thank conference participants at the EFMA 2006 and the Banking Workshop, Münster for valuable comments. Of course, all errors are ours.

2 LMU Munich - Institute for Finance \& Banking, Ludwigstr. 28 RG/V, 80539 Munich, Germany. Email: elsas@bwl.unimuenchen.de, phone: +49 892180 2579, fax: +49 8921803607

${ }^{3}$ European Business School \& E-Finance Lab, Schloß Reichartshausen, 65375 Oestrich-Winkel, Germany. Email: Andreas.Hackethal@ebs.de, phone: +49 6723 69-272, fax: +49 6723 69-208

4 Johann Wolfgang Goethe-University \& E-Finance Lab, Mertonstrasse 17, 60054 Frankfurt/Main, Germany. Email: holzhaeu@wiwi.uni-frankfurt.de, phone: +49 69 42726019, fax: +49 6942726988
} 


\section{Introduction}

While many non-financial firms around the world have been striving for corporate business focus over the last two decades, many financial services firms and especially banks have been heading in the opposite direction and have instead increased revenue diversification. This paper analyzes empirically whether or not the trend towards diversification in global banking has been in the interests of bank shareholders and it aims to shed light on the channels through which diversification might affect value creation in banking.

The trend among many non-financial firms towards more business focus signifies that the costs associated with diversification generally exceed diversification benefits and consequently, that diversification hurts performance. Excessive costs might arise from inefficient investment decisions over internal capital markets and from increased business complexity and bureaucracy.

Section 3.1 of this paper documents that average diversification levels of the world's largest banks were almost one third higher in 2003 than they had been in 1996. Commercial banks typically increased diversification by moving into fee-based businesses. Banks with already strong fee-based revenues expanded into trading activities. Yet other banks diversified revenues by underwriting insurance contracts.

The disparate diversification trends between non-financial firms and banks raises the question of whether many banking institutions are prone to make the same mistakes that many non-financial firms made during the conglomeration wave of the sixties and nineties of the last century or whether the banking business is truly special in the sense that a broadening of business scope creates value for bank shareholders. Such value creation could come from two broad sources. One is bank-specific economies of scope. Unlike most firms from other industries, banks often entertain long-term contractual relationships with their customers. Over time banks can gather extensive customer information and reuse that information not only in the business area where the information was originally gathered but also in other non-related business areas. Moreover, banks that operate with high operational leverage (i.e., a high ratio of fixed costs to variable costs) 
might find that diversification into related businesses awards them with a cost advantage over specialized competitors. For example, selling life insurance through the existing retail bank branch network might result in cost economies of scope. If such economies of scope truly exist in banking, diversification will tend to have positive effects on aggregate welfare and financial system stability.

The second reason why business diversification might be in the interest of bank shareholders has to do with the current state of the entire financial services industry. Mainly due to technological progress and deregulation, the financial services industry has been undergoing dramatic change over the last two decades. It is still far from clear how precisely the industry will develop in the near future and as a consequence which specific business areas will offer the highest value creation potential. In a recent paper, Boot 2003 argues that banks have extended their business scope mainly as a strategic response to this business uncertainty. Banks have been investing into diverse business areas early on to acquire the skills needed to make efficient production decisions and to reap profits when a particular business area eventually turns out to flourish. Given the real option character of skill building investments, wealth implications for shareholders of diversifying financial institutions are a function of the degree of strategic uncertainty, the effectiveness of early skill building or skill reusing, and ultimately the ability of an institution to create shareholder value from the opportunities at hand. It should be clear that this strategy cannot turn out to be successful for all the banks that have embarked on it. Rather one would expect that some institutions will indeed develop into broad powerhouses while others will have to absorb the losses from a failed market entry. If the observed trend towards more diversification was largely driven by such a foot-inthe-door strategy, aggregate effects on welfare and stability are ambiguous at best and bank shareholders as well as regulators should watch diversification trends very carefully.

This paper attempts to provide a fresh view on the direct and indirect effects of revenue diversification on equity market value by disentangling the aggregate diversification effect typically measured by other studies. To that end we measure the effects of diversification on financial indicators from three tiers of a comprehensive framework for bank 
valuation. We also account for potential interactions between diversification, size and vertical integration by explicitly controlling for simultaneous changes along these two other dimensions of banking firm boundaries.

Our main finding is that revenue diversification enhances bank profitability via higher margins from non-interest businesses and lower cost income ratios. We conjecture that revenue and cost economies of scope are non-trivial in financial services and that value creation is not restricted to a few banks that succeeded with their foot-in-the-door strategy. We estimate that the increase in diversification between 1996 and 2003 has increased the average market-to-book ratio of the banks in our sample by more than one tenth and therefore provide evidence for a conglomerate premium in banking.

The paper unfolds as follows. The next section provides a quick review of the relevant empirical literature. Section 3 presents the multi-tier framework for measuring diversification effects. Our data set is presented in section 4. In section 5 we present and discuss our empirical results Section 6 gives further evidence and section 7 concludes.

\section{Literature Review}

There is a large body of literature on the costs and benefits of diversification. Among the identified benefits are economies of scope (e.g., Chandler 1977; Teece 1982), an improved resource allocation through internal capital markets (e.g., Williamson 1975; Stein 1997), a potentially lower tax burden due to higher financial leverage (e.g., Lewellen 1971) and the ability to use firm-specific resources to extend a competitive advantage from one market to another (e.g., Wernerfelt \& Montgomery 1988 and Bodnar et al. 1997). These benefits have to be traded off against the costs associated with diversification. Cost may stem from agency problems afflicting diversifying investments (e.g., Jensen 1986; Meyer et al. 1992), inefficient internal resource allocation due to a malfunctioning of internal capital markets (e.g., Lamont 1997; Scharfstein 1998; Rajan et al. 2000), informational asymmetries between head office and divisional managers (e.g., Harris et al. 1992), and increased incentives for rent-seeking behavior by managers (e.g., Scharfenstein \& Stein 2000). 
There is abundant empirical evidence for US industrial firms that the cost of diversification outweighs its benefits from a shareholder's perspective. The by now classic studies by Lang \& Stulz 1994 and Berger \& Ofek 1995 report that diversified US firms trade at an $8 \%$ and $13 \%$ to $15 \%$ equity discount, respectively, as compared to their specialized peers. However, more recent work has cast some doubt on the general existence of a diversification discount. It has been argued that measurement problems (e.g., Whited 2001), data problems (e.g., Harris 1998; Villalonga 2004), selection biases in terms of firms, observation period or country (Graham et al. 2002; Lins \& Servaes 1999) and failure to account for the endogeneity of the diversification decision (Campa \& Kedia 2002) have driven the results of earlier studies. While the academic debate has not reached a final consensus, a common broad picture emerges according to which value creating diversification is rather the exception than the rule in most industries.

The empirical literature on the merits of bank diversification has largely focused on the question of whether the repeal of the Glass-Steagall Act allowed US commercial banks to reduce business risk by diversifying into non-traditional financial services. The potential to reduce earnings volatility was found for combinations of earnings streams from banking and insurance activities (Boyd et al. 1993; Laderman 1999; Lown et al. 2000) but was hardly found at all for the combination of earnings streams from interestbased banking activities and fee-based securities activities (Allen \& Jagtiani 2000; Estrella 2001).

Stiroh \& Rumble 2003 measure the effect of diversification on the risk-adjusted profitability of US financial holding companies for the period 1997-2002. They find that revenue diversification towards fee income reduced risk-adjusted returns because over their observation period, fee-based activities were more volatile but not necessarily more profitable than traditional interest earning activities. The lack of evidence for positive diversification effects on profitability is echoed by event studies on diversifying bank mergers (e.g., DeLong 2001) and by the abundant empirical literature that applies frontier efficiency analysis to examine the productive efficiency of banks. In their extensive survey article Berger \& Humphrey 1997 report that there is a lack of strong evidence in favor of or against the joint provision of different financial services. 
Laeven \& Levine 2005 apply a modification of Lang \& Stulz 1994 'chop shop’ method to measuring diversification effects on bank market valuation. They compare the market-to-book ratio of a diversified financial institution with that of a corresponding portfolio of selected banks specializing in either interest-based or fee-based business. They assume a linear relationship between diversification and market value and find that diversification reduces market-to-book by up to ten percentage points.

In summary, existing empirical evidence suggests that banking does not seem to be an exception to the broad rule applicable to other industries, namely that diversification costs typically outweigh diversification benefits.

Our paper provides a fresh view on diversification effects in banking by introducing an innovative measurement approach. We adopt a comprehensive framework (see next section) that permits us to measure diversification effects both on accounting-based financial indicators and on market valuations. Moreover we allow for a non-linear relationship between diversification and performance and control for bank characteristics such as the degree of vertical integration and the growth pattern.

\section{Methodology}

To investigate diversification effects on both a bank's market valuation and its financial performance one needs a consistent bank valuation framework that ties market values to observable financial indicators. This section presents the simple framework that underlies our empirical analysis.

The fundamental value (FV) of a bank's equity equals the present value (PV) of future cash flows to shareholders (CF). Under clean surplus accounting the present value of cash flows is equal to the book value of invested shareholders' capital (IC) plus the present value of future economic value creation, as measured by residual income (RI). 
(1) $F V_{t}=\sum_{T=t+1}^{\infty} P V\left(C F_{T}\right)=I C_{t}+\sum_{T=t+1}^{\infty} P V\left(R I_{T}\right)$

Residual income in period $t$ is defined as excess net operating profits after tax (NOPAT) over a capital charge for the capital invested by shareholders. The capital charge equals invested capital (IC) times the cost of equity (CoE).

(2) $R I_{T}=N O P A T_{T}-\left(I C_{T} * C o E_{T}\right)$

The right-hand side of (2) can also be expressed in terms of the spread between the return and the cost of equity.

(3) $R I_{T}=I C_{T} \cdot\left(\frac{N O P A T_{T}}{I C_{T}}-C o E_{T}\right)$

Inserting (3) into (1) yields:

(4) $F V_{t}=I C_{t}+\sum_{T=t+1}^{\infty} P V\left(I C_{T} \cdot\left(\frac{N O P A T_{T}}{I C_{T}}-C o E_{T}\right)\right)$,

where NOPAT/IC corresponds to the after tax return on equity (ROE)

The fundamental value of a bank's equity can therefore be expressed as a function of today's nominal value of invested capital, the expected growth path of invested capital and the expected development of spread. Given that investors use information on past and current growth and past and current spread to forecast future performance, fundamental values will be a function of a vector of past growth and spread and a vector of parameters that investors believe to be indicative of the future development of economic value creation.

(5) $F V_{t}=f\left(I C_{t}, I C_{t-1}, \ldots\right.$, Spread $_{t}$, Spread $\left._{t-1}, \ldots, X_{t}\right)$

If we assume that market value is a (stochastic) function of fundamental value and if we further assume that book value (BV) is a good proxy for invested capital, we can express the ratio of market value to book value (MTB) as a function of the arguments of $f$ (.) and substitute IC with BV. 
(6) $M T B_{t}=\frac{M V_{t}}{B V_{t}}=\frac{g\left(F V_{t}, \varepsilon\right)}{B V_{t}}=h\left(B V_{t}, B V_{t-1}, \ldots\right.$, Spread $_{t}$, Spread $\left._{t-1}, \ldots, X_{t}\right)$

Equation (6) implies that there are two channels through which diversification could affect the relative market valuation of banks. Firstly, if economies of scope exist in banking, then current spreads should be ceteris paribus higher for diversified banks than for specialized banks, and diseconomies of scope should in turn result in lower spreads and lower relative market valuations. The second channel is closely related to the foot-inthe-door strategy mentioned in the introduction of this paper. If investors expect diversification to generate real options that allow banks to quickly grasp and exploit business opportunities as they occur, then diversification should have a positive impact on future growth paths and future developments of spreads. If investors expect diversification to increase future business complexity and bureaucracy, then current diversification should bear negatively on future value creation. In both cases the vector $\mathrm{X}$ should contain a measure for diversification. Multiple countervailing effects might of course also give rise to a non-linear relationship between diversification and MTB and possibly to an optimal degree of diversification. Our estimation model for market-to-book (MTB) in equation (7) below therefore also contains a quadratic term for diversification (DIV).

$$
\begin{aligned}
\text { MTB }_{i, t}= & a+b \cdot B V_{i, t}+c \cdot B \text { Vgrowth }_{, t}+d \cdot \operatorname{SPREAD}_{i, t} \\
& +x_{1} \cdot D I V_{i, t}+x_{2} \cdot D I V_{i, t}{ }^{2}+\varphi^{\prime} \cdot X_{i, t}+\varepsilon_{i, t}
\end{aligned}
$$

$\mathrm{X}$ contains further possible determinants of future performance, such as the degree of vertical integration.

Note that coefficients $\mathrm{x}_{1}$ and $\mathrm{x}_{2}$ measure the effect of current diversification on investor expectations regarding future growth and spread. If they are found to be statistically insignificant, this could cast doubt on the foot-in-the-door channel of diversification. Insignificant coefficients on diversification in our MTB-model, however, do not rule out the economies-of-scope channel of diversification because such diversification effects will be fully captured by the variables spread and growth.

In order to investigate the economies-of-scope channel we estimate diversification effects on spread and on its components. Spread equals pretax operating ROE times one 
minus the corporate tax rate minus the cost of equity. Equation (8) decomposes pre-tax operating ROE into four performance indicators:

(8) SPREAD $=\underbrace{\frac{A_{t}}{B V_{t}} \cdot\left(\frac{T N O R_{t}}{A_{t}}-\frac{T O E_{t}}{A_{t}}-\frac{L L P_{t}}{A_{t}}\right)}_{\text {Pretax Operding Income }} \cdot(1-T)-C o E_{t}$,

where A denotes total assets, TNOR denotes total net operating revenues, TOE denotes total operating expenses and LLP denotes loan loss provisions.

The ratio total net operating revenues over assets can be further decomposed into four asset margins: net interest revenues over assets, net fee revenues over assets, net trading revenues over assets and net other operating revenues over assets. Figure 2 provides a graphical representation of equation (8).

We estimate eight models that have either leverage (assets over book equity), one of the four asset margins, expenses over assets, loan loss provisions over assets or the cost of equity as the dependent variable.

(9) $Y_{i, t}=a+z_{1} \cdot D I V_{i, t}+z_{2} \cdot D I V_{i, t}^{2}+\varphi^{\prime} \cdot X_{i, t}+\varepsilon_{i, t}$

$\mathrm{X}$ contains common control variables for vertical integration, growth, size, systematic risk, business focus and interaction terms. We take the panel nature of our data into account by using fixed-effects regressions, and control for any time variation or macrofactors by including a set of year dummy variables.

A ninth model has spread as the dependent variable. This model is by definition underspecified because it does not contain the components of spread according to equation (8). If we introduced these components into the estimation model for spread, error terms would be zero by definition. Introducing only subsets of components would be arbitrary. The coefficients $z_{1}$ and $z_{2}$ will indicate whether there exists a relationship between diversification and the individual components of spread. Comparisons across spread component models will allow us to scrutinize how exactly diversification affects performance. An aggregation of diversification effects across spread-component models according to equation (8) will allow us to check for consistency of our estimates. The aggre- 
gate effects should be broadly in line with the total effects from regressing SPREAD directly on diversification.

\section{Data}

We obtained accounting and stock price data from the Bankscope Database. The database covers 2,072 bank holding companies from the USA, Canada, Australia, UK, Germany, France, Spain, Italy, and Switzerland. To exclude very small banks we required that the total assets of sample banks exceeded 1bn USD in at least one of the nine years of our observation period. The remaining 1,378 banks from Bankscope were matched with DataStream to obtain banks with available share price information. The final sample contains 380 listed banks with a total of 1,917 observations for the years 1996 to 2003. The number of sample banks was not stable over the years due to mergers and acquisitions. While we kept acquiring banks in the sample, we excluded acquired banks. $65 \%$ of the sample banks are from the US, 3\% are from Canada, $29 \%$ are from Europe and 3\% from Australia.

The CAPM beta of the banks was estimated based on matched DataStream data series. M\&A growth numbers were calculated based on matched M\&A transaction data from the Thomson Financial M\&A Database (see section 4.2 for more details).

\subsection{Definition of Diversification}

Unlike other studies on non-financial industries we cannot measure bank diversification based on SIC codes and segmental accounting data. SIC-code classification for banks is not granular enough and is not consistent across countries. Moreover, segmental reporting is not consistent across banks and across time.

Instead, we use an adjusted Herfindahl-Hirschman index to measure revenue diversification. Various authors have applied a closely related approach (see, e.g., Comment \& Jarrell 1995; Desai \& Jain 1999; Acharya et al. 2002; Stiroh \& Rumble 2003; Stiroh 2004). Equation (10) below shows how our diversification index is constructed. 


$$
D I V=1-\left(\left(\frac{I N T}{T O R}\right)^{2}+\left(\frac{C O M}{T O R}\right)^{2}+\left(\frac{T R A D}{T O R}\right)^{2}+\left(\frac{O T I}{T O R}\right)^{2}\right)
$$

INT denotes gross interest revenue, COM denotes net commission revenue, TRAD denotes net trading revenue, OTI denotes all other net revenue and TOR denotes total revenue. TOR is equal to the sum of the absolute values of INT, COM, TRAD and OTI. ${ }^{5}$

We use gross interest revenue so that our diversification measure is not distorted by the profitability of the bank's interest business. Unfortunately, Bankscope does not consistently report gross numbers for the other revenue categories.

Note that, because we are using gross interest revenue and the absolute values for the other three revenue streams, total operating revenue (TOR) in equation (10) is different from total net operating revenue (TNOR) in equation (8). We subtract the sum of squared revenue shares from unity so that DIV increases in the degree of revenue diversification. By definition DIV can take on values between 0 (the bank is fully specialized on one revenue source) and 0.75 (the bank generates a fully balanced revenue mix from all four revenue sources).

Figure 1 depicts average revenue shares and average diversification levels across all sample banks. Diversification increased from below 30\% in 1996 to over 38\% in 2003. Average diversification levels of US banks increased from $29.8 \%$ to $38.3 \%$ with the highest increase in the years after the abolishment of the Glass-Steagall Act in 1999 (see Table 3). Figure 1 also indicates that the overall increase in diversification is not merely caused by a general decline in the revenue share of interest income. Rather, average revenues shares have remained fairly constant since 1998.

\footnotetext{
${ }^{5}$ Negative net revenue values would lead to negative shares for some revenue streams and shares greater than one for other revenue streams. As a consequence, DIV would be strongly affected by business unit performance and could take on values far greater than 0.75 .
} 


\subsection{Definition of Other Variables}

The level of revenue diversification refers to the horizontal boundaries of a banking firm. Management decisions to alter horizontal boundaries are often intertwined with decisions regarding the level of vertical integration (vertical boundaries) and the overall size and growth of the institution. For example, if business complexity is a positive function of both the level of horizontal diversification and the level of vertical integration and if business complexity bears negatively on performance, then bank management has to trade off horizontal diversification against vertical integration and possibly also against size.

To account for possible interaction effects between the three dimensions of the boundaries of banking firms we need to introduce control variables for size, growth, and vertical integration into our regression analysis.

Following standard definitions we measure size by the natural logarithm of year-end total balance sheet assets. Growth is defined based on the annual percentage change in equity book values. We matched Bankscope data with M\&A transaction data from the Thomson Financial M\&A Database SDC to break down total book equity growth into an M\&A growth component and a residual organic growth component. Because Thomson Financial only reports transactions at market prices we first had to estimate book values for the acquired equity stakes. For that purpose we divided equity market values by the average market-to-book ratio of all banks from the same country as the target in the year of the transaction. We then added book values of all acquisitions and divestitures undertaken by the same bank in a given year and divided that sum by the start-ofyear equity book value of that bank to arrive at an estimate of its M\&A growth in that year. We identified 892 deals that contributed on average 3.8\% to a bank's book equity growth per annum. Organic growth is defined as total growth rate minus M\&A growth rate and amounts to $14.4 \%$ per annum for the average bank in our sample.

The measurement of vertical integration is based on the following idea. We consider a bank as highly vertically integrated if most of its output is generated through the employment of a bank's own resources. A bank is considered to have a low degree of vertical integration if it relies largely on outside resources and services to generate output. 
In accordance with Tucker \& Wilder 1977 (whose approach was adapted to financial services firms by Gellrich \& Holzhäuser 2005) we use gross revenues ${ }^{6}$ as a proxy for output volume and we use the term in equation (11) below to capture the value-add contribution of own resources.

$$
V A_{i, t}=L \operatorname{Exp}_{i, t}+\operatorname{IExp}_{i, t}+L L P_{i, t}+I T_{i, t}+\operatorname{NOPAT}_{i, t}
$$

LExp denotes labor expenses, IExp denotes fixed charges and interest expenses, LLP denotes loan loss provisions, IT denotes income taxes and NOPAT denotes net operating income after tax.

Our metric for the degree of vertical integration (VI) of a bank is defined as follows:

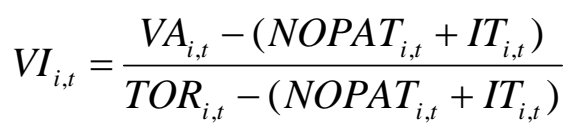

Following Tucker \& Wilder 1977 we subtract pretax operating income from both the numerator and the denominator to adjust the metric for profitability effects. Gellrich \& Holzhäuser 2005 provide evidence that VI as defined above captures changes in the degree of vertical integration fairly accurately. In their panel regression analysis, VI is affected by the extent of a bank's outsourcing activities. For our sample banks the average vertical integration declined from 79.4\% in 1996 to $73.9 \%$ in 2003.

The definitions of the remaining variables follow standard definitions and are reported in Table 1. Table 2 shows the descriptive statistics of the 380 banks in the sample. Data series were windsorized at $0.5 \%$ and $95.5 \%$ quantiles.

\footnotetext{
${ }^{6}$ As mentioned above, Bankscope reports gross figures for interest revenues but only net figures for the other revenue types. Therefore we had to approximate gross revenues from fee-based businesses, trading, and other business based on their corresponding net revenue figures.
} 


\section{Results}

\subsection{Market-to-Book Model}

We start by estimating the model for the market-to-book ratio in equation (7) above. The vector of control variables includes the level of vertical integration, organic growth and M\&A growth, size, the ratio of non-interest income over gross interest income and year dummies. The results for a fixed-effects model with year dummies (not shown) are presented in Table 4.

The coefficients on both the linear and the quadratic term for revenue diversification are statistically insignificant. This indicates that the degree of revenue diversification plays no systematic role for market participants in forecasting future value creation. We view this result as evidence against the existence of a "foot-in-the-door-strategy" channel for diversification. If banks diversify their activities into new fields primarily to ensure that they are amongst the first to exploit further business opportunities that might arise in theses fields, we expect the market to have an opinion on this strategic move. However, the market seems to be indifferent with regard to this strategy or does not believe that this strategy is the true reason why many banks have diversified.

Current shareholder value creation as measured by SPREAD has a highly significant and strongly positive effect on a bank's relative market valuation. Apparently, investors rely to a considerable extent on current value creation when forecasting future value creation. Current organic or M\&A growth does not systematically affect bank valuations.

As discussed above, these results do not rule out the existence of an economies-of-scope channel of diversification. If diversification enhances only current spread but does not affect future growth and spread patterns, relative market valuation will still be a positive function of diversification.

\subsection{Spread and Spread-Component Models}

We start by directly analyzing the relationship between spread and diversification. Note that - as discussed above - a model that uses SPREAD as the dependent variable is by 
definition not correctly specified. Therefore, one should treat the regression results in column (1) of Table 5 as only indicative. Both coefficients on diversification are positive and significantly different from zero, indicating that spread might indeed be a positive (and non-linear) function of diversification.

The spread-component models in Table 5 confirm that diversification strongly affects current value creation and permit a more detailed analysis of how diversification bears on bank profitability. ${ }^{7}$

DIV enters all models through both a linear and a quadratic term. Results regarding the direction of the effect of diversification on the corresponding spread-component are therefore unambiguous if the coefficients on DIV and on squared DIV both carry the same sign or if only one of the two coefficients is statistically significant. This condition is fulfilled in most models but not in the case of the net interest margin and in the case of the cost of equity. Note that the models in Table 5 control for a general trend towards more non-interest revenue via the variable non-interest income over interest income.

All three non-interest income margins appear to be positive and linear functions of diversification, indicating that banks benefit from revenue economies of scope (see columns (2)-(5)). Expenses per asset dollar are also increasing in the degree of diversification (see column (6)), indicating that banks do not benefit from cost economies of scope. However, this result does not hold anymore if one uses the cost-income ratio to measure cost efficiency. Column (7) shows that more diversified banks incur lower expenses per dollar in total revenues. A possible explanation for the discrepancy in both measures is that leverage declines as a consequence of higher diversification (see column (8)). So perhaps expenses over assets increase primarily because diversified banks operate with less assets per dollar in equity and also with less assets per dollar in operating expenses.

Loan loss provisions are only very weakly affected by diversification. The model in column (9) of Table 5 predicts that expected loan losses are slightly higher for diversi-

\footnotetext{
${ }^{7}$ While not shown here we also estimated extended models that feature interaction terms of DIV with the variables for vertical integration and growth. The statistical and economic relevance of diversification effects remained unchanged.
} 
fied banks than for focused banks. This result does not change if we use total revenues instead of total assets as the denominator of the dependent variable.

Column (10) shows that diversification is associated with smaller current equity growth. In the last section we reported that there is no systematic relationship between current equity growth and market valuation. We can therefore largely rule out that diversification reduces market valuations through a deterioration of growth rates.

The estimated effects of diversification on net interest margins and on the cost of equity are not monotonous across the support of DIV. They can be best analyzed by means of numerical examples. The same is true for the aggregate effect of diversification on spread-components. The next section presents numerical examples for the median bank in the sample and three specific bank types.

\subsection{Numerical Examples}

Column 2 in Table 6 reports sample median values for the eight spread-components. We define the median bank from our sample as a bank for which spread-components take on the values shown in column 1. Column 3 reports the estimated change for each of the spread-components if the median bank augments diversification by 10 percentage points (roughly two thirds of the sample standard deviation for DIV). Estimated changes in single spread-components are computed based on the corresponding coefficients on DIV and squared DIV in Table 5. ${ }^{8}$ Aggregate changes on spread are computed based on estimated individual changes in conjunction with equation (8). To verify results on aggregate spread effects we also computed diversification effects on SPREAD based on the coefficients from the regression shown in column (1) of Table 5.

Our model predicts that if the median bank had increased its diversification level from $32 \%$ to $42 \%$, its total revenue margin would ceteris paribus have increased by 62 basis

\footnotetext{
${ }^{8}$ We used both significant and insignificant coefficients. To check whether the results in Table 6 are driven by this procedure we dropped all insignificant variables from the models in Table 5, re-estimated the reduced models and used only significant coefficients for the numerical examples. Estimated effects on spread remained largely unchanged.
} 
points. The slight 10 basis point drop in net interest margin would have been overcompensated by a combined 72 basis point increase in fee, trading and other income margins.

The model also predicts that total operating expenses over assets would have gone up by 22 basis points and that loan loss provisions over assets would have added another 2 basis points to total expenses over assets. Both leverage and cost of equity are estimated to decline slightly as a result of more diversification.

These effects are commensurate with the existence of non-trivial revenue and cost economies of scope in banking. As banks extend their business scope, they might find it easier to (cross-) sell more products to the same customers. In some cases non-interest business can, however, slightly cannibalize a bank's conventional interest-related business, as indicated by the negative diversification effect on the interest margin.

When measured over total revenues, expenses decline in response to diversification (see last row in Table 6). This implies that diversified banks need ceteris paribus fewer inputs to generate the same revenue volume as focused banks. Possible reasons for this result are that revenue diversification permits banks to use some of their resources (e.g., branches, IT systems, brands) more productively.

Table 6 also shows that diversification effects on current spread are quite sizable. Our model for the median bank predicts that individual diversification effects on spreadcomponents add up to a total effect of $4.0 \%$. This estimate is comparable to the $3.2 \%$ increase in spread that is implied by the model in column (1) of Table 5. We conclude that diversification has increased value creation in banking over the past years.

If current spread is a positive function of diversification and if market-to-book is a positive function of current spread, then market-to-book should be a positive function of diversification. If spread increased by four percentage points (e.g., induced by diversification), the model in Table 4 predicts that market-to-book would grow by 22 basis points. Hypothetically, the median bank could have increased its market-to-book ratio from 1.73 to 1.95 through a 10 percentage point push in diversification. 
To see whether our results also hold for specific bank types other than the median bank we selected retail banks, investment banks and universal banks from our sample, computed the group medians for the variables and then estimated diversification on spreadcomponents and spread (refer to Table 8 for selection criteria). Table 6 documents that economies of scope seem to exist for all three bank types and that diversification effects are somewhat stronger for universal banks and somewhat weaker for retail banks than for the median bank. Moreover, Table 6 suggests that aggregate diversification effects are extremely powerful for investment banks. The fact that the corresponding estimate from the model in column (1) of Table 5 is much lower than the aggregate figure indicates that our models and the way we aggregate individual effects into an aggregate effect are less accurate for very high diversification levels.

\section{Further Evidence}

\subsection{Robustness Tests}

Our main result is that increased revenue bank diversification increases the market value of banks through a positive effect on current profitability. This result rests on the assumption that diversification affects profitability, but not the other way around. Since our diversification measure is based on revenues, the two variables can be endogenous. To control for a potential endogeneity bias, we provide two robustness tests. First, we estimate the impact of diversification on the spread, using lagged values of our diversification measure. Second, we apply two-stage least squares (2SLS) and use lagged diversification as the instrument for current diversification. ${ }^{9}$

As can be seen from Table 7, the coefficient on the lagged diversification variable (and the instrumented counterpart) is positive and statistically significant. This confirms our result that an increase in diversification increases bank profitability, even when taking potential endogeneity into account. ${ }^{10}$

\footnotetext{
${ }^{9}$ We do not need to include additional risk measures in the regression model because spread is defined as ROE minus cost of capital, which is based on the estimate of the bank's systematic risk (beta).

${ }^{10}$ Note that including the squared diversification measure does not affect the result.
} 


\subsection{Extended Sample}

The preceding analysis is based on a sample of large, exchange-listed banks. This permitted us to analyze the effect on market valuations. In a separate analysis, we used an extended sample that contains a total of 4,014 bank-year observations from both listed and non-listed banks from the same nine countries. While not shown here, the results for the nine models from Table 5 that we could estimate without market data remained qualitatively the same. ${ }^{11}$

\subsection{Long-Term Operating Performance}

Further evidence for the existence of a positive relationship between diversification and operating bank performance is provided by Holzhäuser 2005. He analyzes how large changes in diversification levels affect subsequent long-term operating performance of US bank holding companies. With a sample of 621 banks covering the years 1990 to 2004 he measures revenue diversification according to equation (10). He finds that industry-adjusted operating return increases on average by $2.2 \%$ over the three years following a major increase in diversification.

Conclusions

\footnotetext{
${ }^{11}$ Results are available from the authors upon request.
} 
This paper is motivated by the observation that over the last decade and all around the world, many banks have become more diversified while many non-financial firms have become more focused with regard to the spectrum of their business activities. If the diversification trend in banking is not just a sign of agency conflicts between weak bank shareholders and empire-building managers, then it must be rooted in structural differences between banking and non-financial industries. We hypothesized that it is either the banking firm and in particular the characteristics of its production function that is special or it is the current state of the banking industry and in particular its high degree of strategic uncertainty that has been very special.

Our empirical results signify that positive diversification effects have outweighed diversification cost in banking and thus largely rule out that bank diversification has solely been a consequence of severe agency conflicts. Moreover, the paper provides evidence through its comprehensive multi-tier empirical framework that diversification benefits are embedded in the production function of most banking firms. Our results suggest that economies of scope (at least among related activities) are stronger in banking than in many other industries. We find no evidence in favor of the hypothesis that banks have diversified primarily in an effort to deal with the strategic uncertainty in their industry (foot-in-the-door strategy), as suggested by Boot 2003. Capital markets have been indifferent with regard to any diversification costs or benefits that go beyond direct effects on current operating performance.

Given that diversification benefits are tied more to the way financial services are produced and less so to the particular challenges the banking industry has been facing over the last decade, it seems likely that banks will also benefit from diversification in the future. And given the fact that a majority of banks still operate at medium levels of diversification, we assume that the industry wide trend towards revenue diversification will continue over the next years.

Finally, on a methodological note, our paper suggests that simple measures of diversification like non-interest revenue over total revenue might in fact be overly simplistic to capture all diversification effects. The same is probably true for econometric models that focus on the direct diversification effects on market valuations. Our paper shows 
that diversification effects do not typically materialize through such direct effects but rather through indirect effects on current operating performance and is thereby able to reveal a conglomeration premium in banking. 


\section{References}

Acharya, V.V., Hasan, I., Saunders, A. 2002. Should banks be diversified? Evidence from individual bank loan portfolios.

Allen, L., Jagtiani, J. 2000. The risk effects of combining banking, securities, and insurance activities. Journal of Economics and Business 52, 485-497.

Berger, A.N., Humphrey, D.B. 1997. Efficiency of financial institutions: International survey and directions for future research. European Journal of Operational Research 98, 175-212.

Berger, P., Ofek, E. 1995. Diversification's effect on firm value. Journal of Financial Economics 37, 39-65.

Bodnar, G.M., Tang, C., Weintrop, J. 1997. Both Sides of Corporate Diversification: The Value Impacts of Geographic and Industrial Diversification. NBER Working Paper

Boot, A.W.A. 2003. Restructuring in the Banking Industry with Implications for Europe. 2003 EIB Conference on Economics and Banking.

Boyd, J.H., Graham, S.L., Hewitt, R.S. 1993. Bank holding company mergers with nonbank financial firms: Effects on the risk of failure. Journal of Banking \& Finance 17, 43-63.

Campa, J.M., Kedia, S. 2002. Explaining the diversification discount. The Journal of Finance 57, 1731-1761.

Chandler, A.D. 1977. The Visible Hand: The Managerial Revolution in American Business. Belknap Press, Cambridge, MA.

Comment, R., Jarrell, G.A. 1995. Corporate Focus and Stock Returns. Journal of Financial Economics 37, 67-87.

DeLong, G.L. 2001. Stockholder gains from focusing versus diversifying bank mergers. Journal of Financial Economics 59, 221-252.

Desai, H., Jain, P.C. 1999. Firm performance and focus: Long-run stock market performance following spinoffs. Journal of Financial Economics 54, 75-101.

Estrella, A. 2001. Mixing and matching: Prospective financial sector mergers and market valuation. Journal of Banking and Finance 25, 2367-2392.

Gellrich, T., Holzhäuser, M. 2005. Lean Banking - Myth or Success Formula? E-Finance Lab Working Paper Series.

Graham, J.R., Lemmon, M.L., Wolf, J. 2002. Does corporate diversification destroy value? The Journal of Finance 57, 695-720.

Harris, M., Kriebel, C., Raviv, A. 1992. Asymmetric Information, Incentives, and Intrafirm Resource Allocation. Management Science 28, 604-620.

Harris, M.S. 1998. The association between competition and managers' business segment reporting decisions. Journal of Accounting Research 36, 111-128.

Holzhäuser, M. 2005. Long-term performance effects of bank diversification. E-Finance Lab Working Paper Series.

Jensen, M.C. 1986. Agency Costs of Free Cash Flow, Corporate Finance, and Takeovers. American Economic Review 76, 323-329.

Laderman, E.S. 1999. The potential diversification and failure reduction benefits of bank expansion into nonbanking activities. Federal Reserve Bank of San Francisco Working Paper Series.

Laeven, L., Levine, R. 2005. Is there a Diversification Discount in Financial Conglomerates? NBER Working Paper 11499.

Lamont, O. 1997. Cashflow and investment: Evidence from internal capital markets. The Journal of Finance 52, 83109.

Lang, L.H.P., Stulz, R.M. 1994. Tobin's q, Corporate Diversification, and Firm Performance. Journal of Political Economy 102, 1248-1280.

Lewellen, W.G. 1971. A Pure Financial Rationale for the Conglomerate Merger. The Journal of Finance 26, 521-537. 
Lins, K., Servaes, H. 1999. International Evidence on the Value of Corporate Diversification. The Journal of Finance 54, 2215-2239.

Lown, C.S., Osler, C.L., Strahan, P.E., Sufi, S. 2000. The changing landscape of the financial services industry: What lies ahead? Federal Reserve Bank of New York, Conference on Specialization, Diversification and the Structure of the Financial System: The Impact of Technological Change and Regulatory Reform.

Meyer, M., Milgrom, P., Roberts, J. 1992. Organizational Prospects, Influence Costs, and Ownership Changes. Journal of Economics and Management Strategy 1, 9-35.

Rajan, R., Servaes, H., Zingales, L. 2000. The Cost of Diversity: The Diversification Discount and Inefficient Investment. The Journal of Finance 55, 35-80.

Scharfenstein, D., Stein, J.C. 2000. Herd Behavior and Investment: Reply. American Economic Review 90, 705-706.

Scharfstein, D. 1998. The dark side of internal capital markets II: Evidence from diversified conglomerates. NBER Working Paper Series.

Stein, J.C. 1997. Internal capital markets and the competition for corporate resources. The Journal of Finance 52, 111-134.

Stiroh, K.J. 2004. Do Community Banks Benefit from Diversification? Journal of Financial Services Research 25, 135-160.

Stiroh, K.J., Rumble, A. 2003. The Darkside of Diversification: The Case of U.S. Financial Holding Companies. Working Paper.

Teece, D.J. 1982. Towards an economic theory of the multiproduct firm. Journal of Economic Behaviour and Organization 3, 39-63.

Tucker, I.B., Wilder, R.P. 1977. Trends in Vertical Integration in the U.S. Manufacturing Sector. The Journal of Industrial Economics 26, 81-94.

Villalonga, B. 2004. Does Diversification Cause the Diversification Discount? Financial Management 33, 5-27.

Wernerfelt, B., Montgomery, C.A. 1988. Tobin’s q and the Importance of Focus in Firm Performance. American Economic Review 78, 246-250.

Whited, T.M. 2001. Is It Inefficient Investment that Causes the Diversification Discount? The Journal of Finance Vol. 56, 1667-1691.

Williamson, O.E. 1975. Markets and Hierarchies: Analysis and Antitrust Implications. Free Press, New York. 


\section{Figure 1: Revenue Composition and Diversification by Year}

The figure shows the mean proportions of the different revenue streams as a percentage of operating revenues. Operating revenue is the sum of the four revenue streams. In addition the graph presents the development of the mean diversification. In total there are 380 banks included in the calculation.

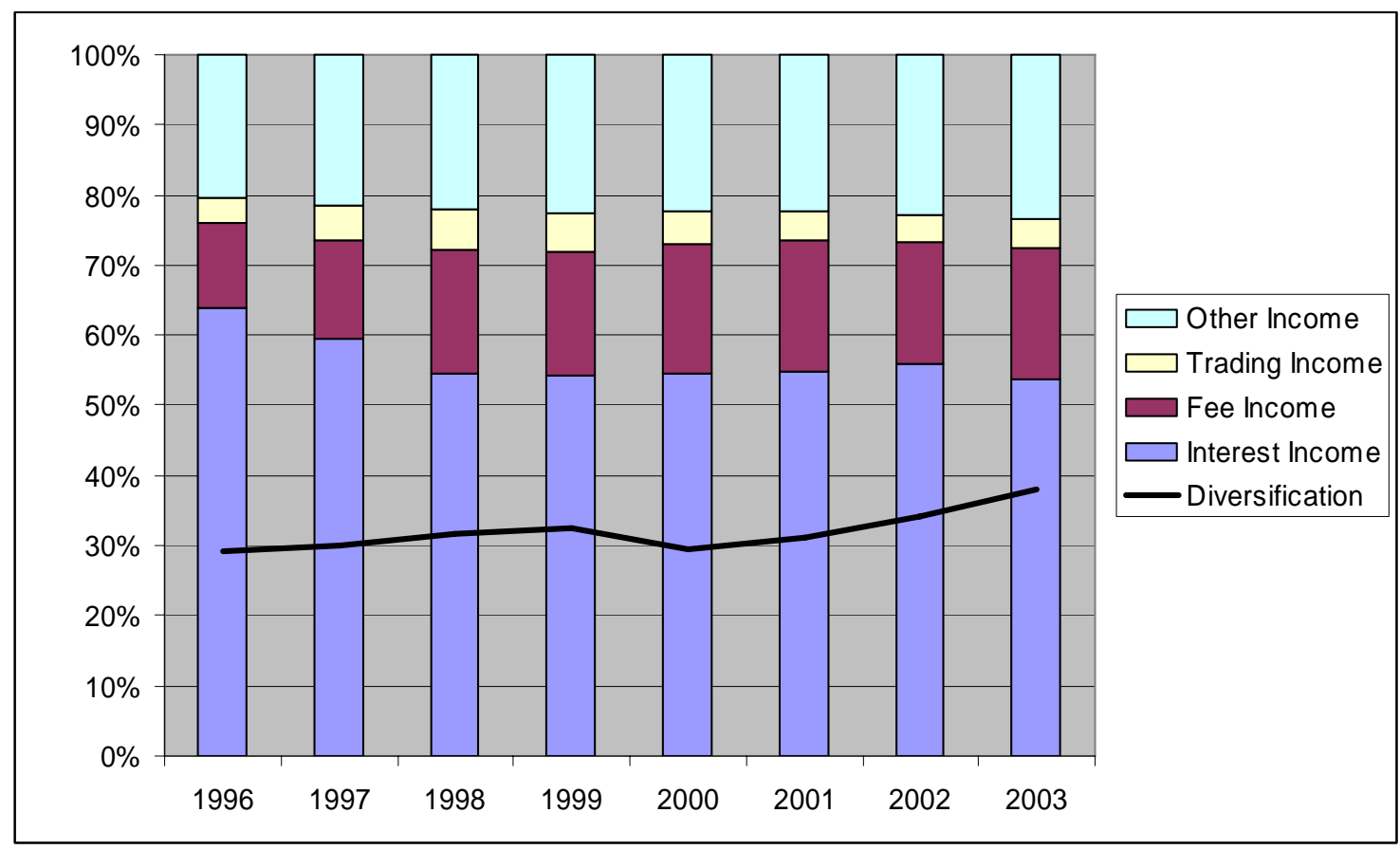

Figure 2: Spread Decomposition

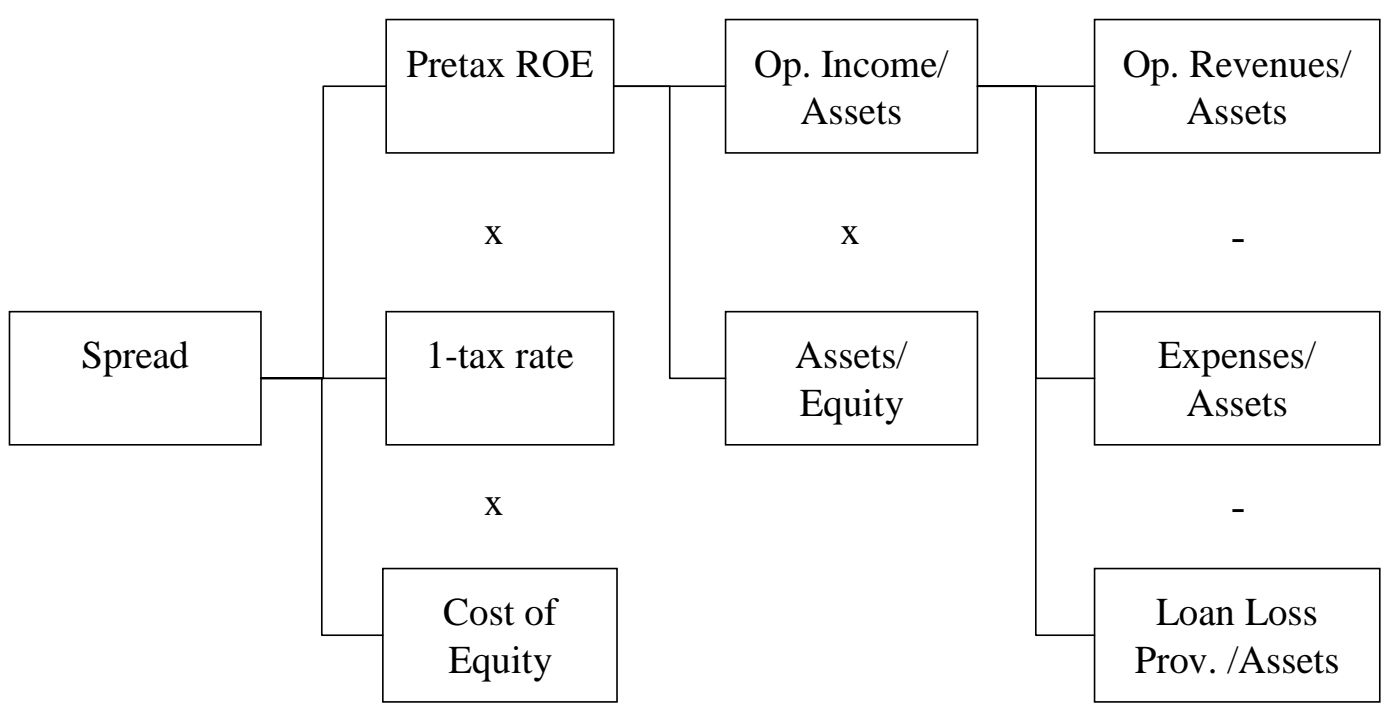


Table 1: Description of Variables

\begin{tabular}{|c|c|}
\hline Diversification & See equation (10) \\
\hline Return on equity & $\begin{array}{l}\text { (Net revenues }- \text { operating expenses }- \text { loan loss provi- } \\
\text { sions)*effective tax rate } /\left(0.5^{*} \text { beginning-of-period book equity }\right. \\
\left.+0.5^{*} \text { end-of-period book equity }\right)\end{array}$ \\
\hline Spread & Return on equity - cost of equity \\
\hline Cost of equity & $0.05+0.05 *$ Beta \\
\hline Market-to-book & Market capitalization on Dec 31\%end-of-year book equity \\
\hline Beta & $\begin{array}{l}\text { Calculated based on } 250 \text { days of data on return indices for bank } \\
\text { and for MSCI World market index (data from DataStream). }\end{array}$ \\
\hline Vertical integration & $\begin{array}{l}\text { (Staff expenses }+ \text { interest expenses }+ \text { loan loss provisions) / } \\
\text { (gross operating revenues }- \text { pretax operating income) }\end{array}$ \\
\hline Equity growth & $\begin{array}{l}\text { (end-of-period book equity / beginning-of-period book equity) - } \\
1\end{array}$ \\
\hline M\&A growth & $\begin{array}{l}\text { (Aggregate deal value from acquisitions and divestitures per } \\
\text { bank) / (beginning-of-period book equity) }-1\end{array}$ \\
\hline Organic growth & $(1+$ equity growth $) /(1+$ M\&A growth $)-1$ \\
\hline
\end{tabular}


Table 2: Descriptive Statistics

\begin{tabular}{lccccc}
\hline & Obs & Mean & Std.Dev. & Min & Max \\
\hline Bank Structure & & & & & \\
Diversification & 1917 & $32.7 \%$ & $14.1 \%$ & $0.0 \%$ & $70.6 \%$ \\
Vertical integration & 1917 & $77.7 \%$ & $9.4 \%$ & $36.4 \%$ & $110.7 \%$ \\
Total Assets (in USDbn) & 1917 & 61.6 & 145.3 & 0.1 & 1264.0 \\
Growth & & & & & \\
Growth due to M\&A buys & 1917 & $3.8 \%$ & $11.9 \%$ & $0.0 \%$ & $93.1 \%$ \\
Organic Growth & 1917 & $14.4 \%$ & $27.4 \%$ & $-97.1 \%$ & $263.6 \%$ \\
Shareholder value & & & & & \\
ROE & 1917 & $17.5 \%$ & $10.0 \%$ & $-35.8 \%$ & $56.1 \%$ \\
Spread & 1917 & $3.8 \%$ & $6.7 \%$ & $-34.6 \%$ & $23.0 \%$ \\
Market-to-book & 1917 & 1.995 & 1.439 & 0.075 & 11.351 \\
Revenue composition & & & & & \\
Interest income & 1917 & $62.7 \%$ & $21.8 \%$ & $-76.9 \%$ & $102.8 \%$ \\
Fee income & 1917 & $15.2 \%$ & $15.5 \%$ & $-4.0 \%$ & $91.1 \%$ \\
Trading income & 1917 & $3.9 \%$ & $9.6 \%$ & $-15.9 \%$ & $133.3 \%$ \\
Other operating income & 1917 & $18.2 \%$ & $19.3 \%$ & $-3.4 \%$ & $193.0 \%$ \\
Operations & & & & & $15 \%$ \\
Cost/income & 1917 & $62.8 \%$ & $14.5 \%$ & $19.6 \%$ & $153.4 \%$ \\
Expenses/assets & 1917 & $3.3 \%$ & $2.6 \%$ & $0.2 \%$ & $23.4 \%$ \\
Non-interest income/interest income (gross) & 1917 & $65.1 \%$ & $230.5 \%$ & $-1.1 \%$ & $2709.3 \%$ \\
Loan loss provisions/assets & 1917 & $0.00031 \%$ & $0.00040 \%$ & $-0.00028 \%$ & $0.00314 \%$ \\
Risk & & & & & \\
Assets/equity & 1917 & 13.438 & 6.176 & 1.502 & 62.106 \\
Beta & 1917 & 0.644 & 0.475 & -0.634 & 1.964 \\
\hline
\end{tabular}

\section{Table 3: Development of Diversification}

Summary statistic of the development of the diversification measure in the US compared to Europe from 1996-2003.

\begin{tabular}{lcccccccc}
\hline & $\mathbf{1 9 9 6}$ & $\mathbf{1 9 9 7}$ & $\mathbf{1 9 9 8}$ & $\mathbf{1 9 9 9}$ & $\mathbf{2 0 0 0}$ & $\mathbf{2 0 0 1}$ & $\mathbf{2 0 0 2}$ & $\mathbf{2 0 0 3}$ \\
\hline USA & $29.8 \%$ & $30.3 \%$ & $31.7 \%$ & $31.3 \%$ & $27.5 \%$ & $30.3 \%$ & $34.3 \%$ & $38.3 \%$ \\
Europe & $28.2 \%$ & $28.8 \%$ & $31.9 \%$ & $34.6 \%$ & $34.8 \%$ & $33.3 \%$ & $33.7 \%$ & $37.2 \%$ \\
Total sample & $29.3 \%$ & $29.9 \%$ & $31.8 \%$ & $32.5 \%$ & $29.6 \%$ & $31.2 \%$ & $34.3 \%$ & $38.0 \%$ \\
\hline
\end{tabular}




\section{Table 4: Market-to-Book Ratio}

The table reports the results for a fixed-effects model with market-to-book (MTB) as dependent variable. $*{ }^{* *}, * * *$ denote significance at the $10 \%, 5 \%$ and $1 \%$-level, respectively. The full model includes year dummies (not shown here).

\begin{tabular}{lcc}
\hline & Market-to-book ratio \\
\hline & coefficient & p-value \\
Diversification & -0.825 & 0.311 \\
(Diversification)^2 $^{\wedge}$ & 1.008 & 0.417 \\
Vertical Integration & -4.551 & 0.128 \\
(Vertical Integration )^2 & 2.551 & 0.171 \\
Spread & $5.813 * * *$ & 0.000 \\
Growth due to M\&A buys & -0.224 & 0.218 \\
Organic Growth & 0.085 & 0.277 \\
Log(assets) & $-1.474 * * *$ & 0.000 \\
Non-interest income/interest income (gross) & $-0.117 * * *$ & 0.000 \\
Constant & $17.668 * * *$ & 0.000 \\
& & \\
$\mathrm{~N}$ & 1917 & \\
Groups & 380 & \\
$\mathrm{R}^{2}$ & 0.3179 & \\
F-Test & $44.31 * * *$ & 0.000 \\
\hline
\end{tabular}




\section{Table 5: Spread and Spread-Components}

The table reports the results from fixed effects regression models. Dependent variables are in column headers. *,**,*** denote significance at the $10 \%, 5 \%$ and 1\%-level, respectively. The full models include year dummies (not shown here).

\begin{tabular}{|c|c|c|c|c|c|c|c|c|c|c|}
\hline \multirow[b]{3}{*}{ Diversification } & \multicolumn{2}{|c|}{ Spread (1) } & \multicolumn{2}{|c|}{$\begin{array}{c}\text { Net interest } \\
\text { income/assets (2) }\end{array}$} & \multicolumn{2}{|c|}{ Fee income/assets (3) } & \multicolumn{2}{|c|}{$\begin{array}{c}\text { Trading } \\
\text { income/assets (4) }\end{array}$} & \multicolumn{2}{|c|}{$\begin{array}{c}\text { Other income/assets } \\
\text { (5) } \\
\end{array}$} \\
\hline & coefficient & p-value & coefficient & p-value & coefficient & p-value & coefficient & p-value & coefficient & p-value \\
\hline & $0.099 * *$ & 0.023 & $-0.056 * * *$ & 0.000 & $0.015 * *$ & 0.010 & $0.006 *$ & 0.054 & $0.029 * * *$ & 0.000 \\
\hline Vertical Integration & $1.085 * * *$ & 0.000 & $0.037 * * *$ & 0.002 & -0.028 & 0.177 & $0.020 *$ & 0.076 & $-0.139 * * *$ & 0.000 \\
\hline $\begin{array}{l}(\text { Vertical Integration })^{\wedge} 2 \\
\text { Spread }\end{array}$ & $-0.434 * * *$ & 0.000 & $-0.029 * * *$ & 0.000 & 0.011 & 0.409 & -0.008 & 0.273 & $0.081 * * *$ & 0.000 \\
\hline Growth due to M\&A buys & $-0.037 * * *$ & 0.000 & $-0.002 * * *$ & 0.009 & 0.000 & 0.900 & 0.000 & 0.998 & 0.001 & 0.613 \\
\hline Organic Growth & -0.004 & 0.349 & $-0.001 * * *$ & 0.000 & $0.001 *$ & 0.097 & $0.001 *$ & 0.064 & 0.000 & 0.460 \\
\hline Log(assets) & $-0.011 * *$ & 0.040 & $-0.002 * * *$ & 0.000 & $-0.004 * * *$ & 0.000 & $-0.001 * *$ & 0.014 & $-0.004 * * *$ & 0.000 \\
\hline Non-interest income/interest income (gross) & $0.006 * * *$ & 0.000 & $-0.001 * * *$ & 0.000 & $-0.001 * * *$ & 0.000 & $0.001 * * *$ & 0.000 & $0.004 * * *$ & 0.000 \\
\hline Beta & & & 0.000 & 0.133 & 0.000 & 0.531 & 0.000 & 0.205 & 0.000 & 0.456 \\
\hline Constant & $-0.486 * * *$ & 0.000 & $0.055 * * *$ & 0.000 & $0.056 * * *$ & 0.000 & -0.003 & 0.644 & $0.099 * * *$ & 0.000 \\
\hline $\mathrm{N}$ & 1917 & & 1917 & & 1917 & & 1917 & & 1917 & \\
\hline Groups & 380 & & 380 & & 380 & & 380 & & 380 & \\
\hline F-Test & $30.95 * * *$ & 0.000 & $47.34 * * *$ & 0.000 & $13.47 \quad * * *$ & 0.000 & $13.03 * * *$ & 0.000 & $39.91 * * *$ & 0.000 \\
\hline
\end{tabular}




\section{Table 5: Spread and Spread-Components (cont.)}

The table reports the results from fixed effects regression models. Dependent variables are in column headers. $* * *, * * *$ denote significance at the $10 \%, 5 \%$ and $1 \%$-level, respectively. The full models include year dummies (not shown here).

\begin{tabular}{|c|c|c|c|c|c|c|c|c|c|c|c|c|}
\hline & \multicolumn{2}{|c|}{ Expenses/assets (6) } & \multicolumn{2}{|c|}{ Cost/income ratio (7) } & \multicolumn{2}{|c|}{ Assets/equity (8) } & \multicolumn{2}{|c|}{$\begin{array}{c}\text { Loan loss } \\
\text { provisions/assets (9) }\end{array}$} & \multicolumn{2}{|c|}{ Cost of equity (10) } & \multicolumn{2}{|c|}{ Equity growth (11) } \\
\hline & coefficient & p-value & coefficient & p-value & coefficient & p-value & coefficient & p-value & coefficient & p-value & coefficient & p-value \\
\hline Diversification & -0.010 & 0.137 & $-0.152 * *$ & 0.021 & -0.839 & 0.686 & -0.002 & 0.235 & $0.022 *$ & 0.090 & $-2.774 * * *$ & 0.003 \\
\hline$(\text { Diversification })^{\wedge} 2$ & $0.044 * * *$ & 0.000 & -0.123 & 0.219 & $-5.965 *$ & 0.059 & $0.006 *$ & 0.075 & $-0.059 * * *$ & 0.003 & 0.212 & 0.663 \\
\hline Vertical Integration & $-0.261 * * *$ & 0.000 & $-2.618 * * *$ & 0.000 & -9.598 & 0.201 & -0.005 & 0.551 & -0.015 & 0.746 & -1.723 & 0.160 \\
\hline $\begin{array}{l}\text { (Vertical Integration })^{\wedge} 2 \\
\text { Spread }\end{array}$ & $0.127 * * *$ & 0.000 & $1.237 * * *$ & 0.000 & $9.214 *$ & 0.052 & $0.008 *$ & 0.090 & 0.012 & 0.673 & 0.305 & 0.649 \\
\hline Growth due to M\&A buys & $0.004 * * *$ & 0.005 & $0.080 * * *$ & 0.000 & $-1.833 * * *$ & 0.000 & 0.000 & 0.486 & -0.004 & 0.158 & & \\
\hline Organic Growth & 0.000 & 0.496 & $0.016 * *$ & 0.012 & $-1.574 * * *$ & 0.000 & 0.000 & 0.178 & $-0.003 * *$ & 0.021 & & \\
\hline Log(assets) & $-0.011 * * *$ & 0.000 & $-0.019 * *$ & 0.016 & $1.516 * * *$ & 0.000 & 0.000 & 0.759 & $0.008 * * *$ & 0.000 & $0.327 * * *$ & 0.000 \\
\hline Non-interest income/interest income (gross) & $0.001 * * *$ & 0.000 & $-0.010 * * *$ & 0.000 & $-0.239 * * *$ & 0.002 & 0.000 & 0.216 & 0.000 & 0.763 & 0.010 & 0.324 \\
\hline Beta & 0.000 & 0.918 & 0.006 & 0.330 & 0.101 & 0.623 & 0.000 & 0.977 & & & $-0.074 * * *$ & 0.006 \\
\hline Constant & $0.259 * * *$ & 0.000 & $2.045 * * *$ & 0.000 & 3.459 & 0.349 & 0.000 & 0.951 & 0.016 & 0.477 & $-1.056 *$ & 0.097 \\
\hline $\mathrm{N}$ & 1917 & & 1917 & & 1917 & & 1917 & & 1917 & & 1917 & \\
\hline Groups & 380 & & 380 & & 380 & & 380 & & 380 & & 380 & \\
\hline $\mathrm{R}^{2}$ & 0.3379 & & 0.2269 & & 0.1337 & & 0.0911 & & 0.1215 & & 0.1268 & \\
\hline F-Test & $45.64 * * *$ & 0.000 & $26.24 * * *$ & 0.000 & $14.67 * * *$ & 0.000 & $8.96 * * *$ & 0.000 & $13.15 * * *$ & 0.000 & $13.8 * * *$ & 0 \\
\hline
\end{tabular}




\section{Table 6: Hypothetical Changes in Operating Performance Given an Increase in Diversification}

The table reports the estimated change in spread-components, spread and market-to-book ratio if diversification level is increased by 10 percentage points. Changes for spread-components are calculated based on the corresponding coefficients in Table 5 and median values per bank type. The aggregate effect on spread is computed based on estimated changes in the spread-components and based on equation (8). The estimated effect on spread is computed based on the coefficients in column (1) of Table 5. The effect on market-to-book is computed by entering the aggregate effect on spread in the model from Table 4. Bank type definitions are reported in Table 8.

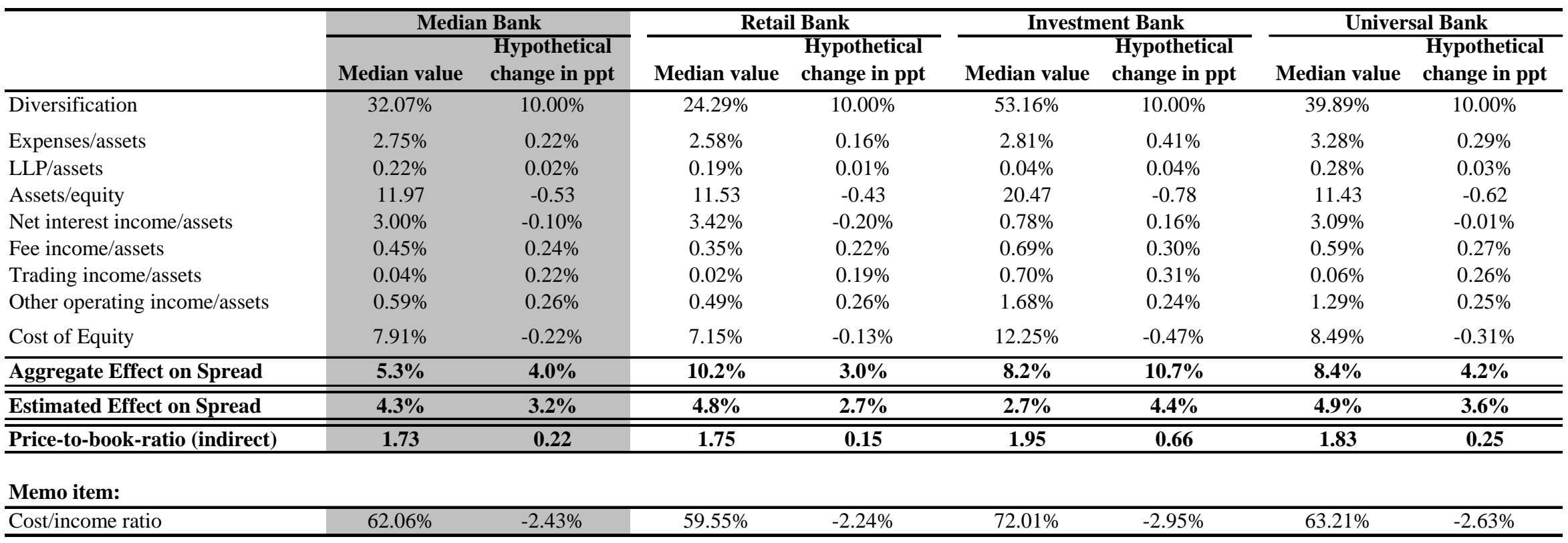




\section{Table 7: Robustness Regressions}

The table shows regression results for various robustness tests of our results in Table 4 . For a definition of the variables, see Table 1. Estimator denotes the applied estimation technique, where FE is fixed effects and 2SLS is two-stage least squares. The first row denotes the dependent variable. *, **, *** denote significance at the $1 \%, 5 \%$, and $10 \%-$ level, respectively.

\begin{tabular}{|c|c|c|c|c|}
\hline & \multicolumn{2}{|c|}{ Spread } & \multicolumn{2}{|c|}{ Spread } \\
\hline & Coefficient & p-value & Coefficient & p-value \\
\hline Diversification & --- & & --- & \\
\hline Diversification (Lag 1 / Instrumented) & $0.161 * * *$ & 0.000 & $0.405 * * *$ & 0.000 \\
\hline Non-interest income/interest income (gross) & 0.002 & 0.287 & $0.008 * * *$ & 0.000 \\
\hline Growth due to M\&A buys & $-0.031 * * *$ & 0.007 & $-0.029 * * *$ & 0.009 \\
\hline Organic Growth & -0.003 & 0.948 & -0.005 & 0.253 \\
\hline Vertical Integration & $1.056 * * *$ & 0.000 & $0.913 * * *$ & 0.000 \\
\hline$(\text { Vertical Integration })^{\wedge}$ & $-0.455 * *$ & 0.000 & $-0.303 * * *$ & 0.006 \\
\hline $\log$ (assets) & $-0.023 * * *$ & 0.000 & $-0.022 * * *$ & 0.000 \\
\hline Estimator & \multicolumn{2}{|c|}{ Panel FE with Year } & \multicolumn{2}{|c|}{ Panel FE, 2SLS } \\
\hline $\mathrm{N}$ & \multicolumn{2}{|c|}{1595} & \multicolumn{2}{|c|}{1595} \\
\hline Adj. R2 & \multicolumn{2}{|c|}{0.2} & \multicolumn{2}{|c|}{0.25} \\
\hline
\end{tabular}

\section{Table 8: Categorization of Banks}

This table reports the criteria for categorizing sample banks.

\begin{tabular}{lccc}
\hline & Investment bank & Universal bank & Retail bank \\
\hline Deposits/assets & $<40 \%$ & $>60 \%$ & $>70 \%$ \\
Loans/assets & & $>50 \%$ & \\
Gross interest income/assets & $<75 \%$ & $<80 \%$ & $>80 \% *$ \\
\hline
\end{tabular}

* Additionally: Trading income/operating income <5\% 